\title{
Electronic Portfolio for Assessment of Engineering
}

\author{
Dominic M. Halsmer, PhD, PE, Professor, Chair \\ Engineering and Physics Department \\ Oral Roberts University \\ 7777 S. Lewis Ave. \\ Tulsa, OK 74171 \\ 918-495-6935 \\ dhalsmer@oru.edu
}

\begin{abstract}
In an effort to continuously improve the quality of education in the general engineering program at Oral Roberts University, a new tool known as Electronic Portfolio or e-Portfolio has been implemented as the primary data-gathering instrument for assessment. Students periodically submit exhibits to the portfolio as evidence that educational objectives are being met. Not only does this provide good information for program improvement, but it also allows the students to see more clearly how their lives are being transformed. This is highly motivating for both students and faculty, and it also helps to streamline the ongoing assessment process.
\end{abstract}

Students take a more active role in helping to assess their education by electronically submitting evaluations, coursework, test scores, and survey results at the entry, intermediate, and capstone levels. These exhibits are carefully selected to demonstrate satisfaction of the program educational objectives, which are derived from departmental and university mission statements, ABET evaluation criteria, and input from other constituents. A professional level may also be added to facilitate the gathering of information from alumni, employers, and graduate school advisors. Data is then aggregated, disaggregated, and evaluated to assist in making program improvements. The e-Portfolio effectively serves as an individualized web site for each student. Multiple e-Portfolios may be developed by each student for different purposes. A growth portfolio highlights improvements in student's knowledge and abilities. A portfolio developed for a prospective employer or graduate school highlights the student's best work. Faculty may also customize e-Portfolios to meet their individual needs. University-wide implementation issues are discussed including the necessary training for students to use the software effectively, and advisor responsibilities. 
Oral Roberts University's academic vision is to transform students by the power of the Holy Spirit into whole, competent servant-leaders through liberal arts and professional education that is fully Christian. Within a Spirit-filled, healing community, administration, faculty, and staff love and serve students by helping them grow in knowledge, skills, wisdom, character, and spirit. ${ }^{1}$ Part of this vision is realized through the pursuit of excellence in the ORU Engineering, Physics, and Physical Science Department, which offers a Bachelor of Science in Engineering Degree with concentrations in mechanical engineering, electrical engineering, and computer engineering. Bachelor of Science Degrees in Biomedical Engineering, Engineering Physics, and Science Education are also offered through the department. There are approximately 75 students currently pursuing these undergraduate majors, with the vast majority selecting the Bachelor of Science in Engineering Degree, which is ABET accredited. All students in these majors will begin the development of personal electronic portfolios this semester (spring of 2004).

The mission of the department is to provide students with the knowledge, skills, and experiences that will prepare them to enter directly into professional practice as Christian engineers, or into advanced studies in engineering, or other professional areas. This training equips students in the application of science and mathematics for the improvement of the physical world, and enables graduates to enter the engineering and scientific communities, and contribute to the healing of the human condition. The department supports the overall university mission by the development of analytical thinking and problem solving in science and engineering, and promotes understanding and reconciliation between the fields of science and theology. A team of engineering students and faculty members have developed a rough draft of a conceptual framework for the department as illustrated in Figure 1.

\section{Measuring a Transformed Life}

The Bible admonishes us with the following words from Paul's Letter to the Romans, "Do not conform any longer to the pattern of this world, but be transformed by the renewing of your mind. Then you will be able to test and approve what God's will is - His good, pleasing and perfect will. ${ }^{2}$ In 2003, the ORU School of Education began implementing a tool called Electronic Portfolio (or e-Portfolio) to assist them in the transformation of their students, and in the demonstration of this transformation to their constituencies, including their accreditation agency. With the help of the ORU School of Education, and a company called Chalk and Wire ${ }^{3}$, the ORU Engineering, Physics, and Physical Science Department has begun implementation of a tool of this same form. In fact, every academic department of the entire university is planning to implement this tool within the next year.

E-Portfolio is a secure, web-based electronic portfolio that allows for the collection of student artifacts, or exhibits; the assessment of those artifacts, and the analysis of the resulting data for program and university improvement ${ }^{4}$. Exhibits are chosen to demonstrate the satisfaction of program outcomes in the lives of the students. The conceptual framework for the department, along with ABET criteria for general engineering programs ${ }^{5}$ and input from other constituents, guide in the development of the departmental mission and program outcomes. The following is a summary of the program outcomes for the Engineering Major.

"Proceedings of the 2004 American Society for Engineering

Education Annual Conference \& Exposition 


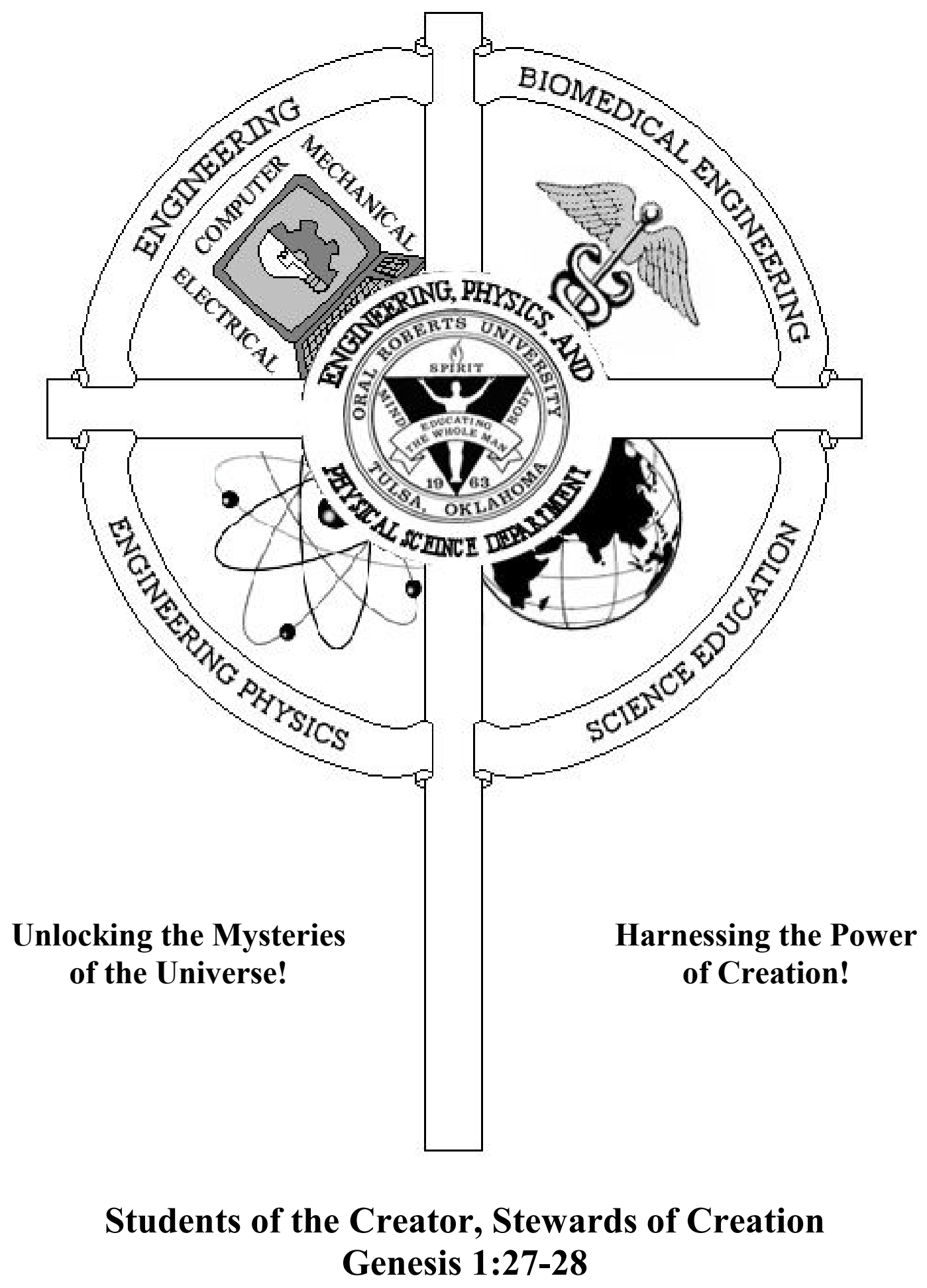

Figure 1. Conceptual Framework for Oral Roberts University

Engineering, Physics, and Physical Science Department

"Proceedings of the 2004 American Society for Engineering

Education Annual Conference \& Exposition

Copyright (C) 2004, American Society for Engineering Education" 
1. Graduates are able to apply knowledge of mathematics, science, and engineering.

2. Graduates are able to design and conduct experiments, as well as analyze and interpret data.

3. Graduates are able to design a system, component, or process to meet desired needs.

4. Graduates are able to function on multi-disciplinary teams.

5. Graduates are able to identify, formulate, and solve engineering problems.

6. Graduates understand professional and ethical responsibility.

7. Graduates are able to communicate effectively.

8. Graduates have a broad education necessary to understand the impact of engineering solutions in a global and societal context.

9. Graduates recognize the need for, and are able to engage in life-long learning.

10. Graduates have knowledge of contemporary issues.

11. Graduates are able to use the techniques, skills, and modern tools necessary for engineering practice.

12. Graduates are able to apply Christian principles of stewardship.

Students submit exhibits to a personal "website" via the internet along with demographic information which allows for aggregation and disaggregation of data for program improvement. Faculty members develop rubrics for evaluation of exhibits and assessment of student work. Since students have access to their e-Portfolio accounts for a minimum of eight years, it is planned to gather additional data from graduates on an ongoing basis. Portfolio exhibits include supporting documents, evaluations and recommendations, evidence of competencies, written samples, projects, evidence of creativity and performance, and evidence of extracurricular activities. Hardcopy items may be entered by using a scanner. Specific choices for engineering exhibits are shown in Table 1. Table 2 presents an assessment rubric that was developed to assess an exam from the course: EGR 221 Mechanics I: Statics.

Implementation and Expectations

A new course was created to introduce students to this new initiative. A non-credit seminar course, "E-Portfolio: Journey to a Transformed Life" will be required for all students. The course is designed to impart ORU's vision and mission and the rationale behind e-Portfolio. Students are introduced to university-wide and program specific "Learning Outcomes" and gain an understanding of our mission of developing a "whole person to go into every person's world." This pass-fail course is presented in two parts and has a total of 5.5 contact hours. During the first part, the Vice President for Academic Affairs casts the vision, presents the rationale, and outlines the purpose of the course. In the second part, students engage in a technology lab for two 2-hour class sessions to learn how to construct their e-Portfolio online through Chalk and Wire, the service provider. Students are supervised and trained by department faculty representatives who serve as departmental assessment coordinators, and are assisted by student technology trainers. ${ }^{4}$ Each student has been allocated 60 Megabytes of space in which to store their exhibits. There is some concern that this may not be enough space, considering the three required video clips. However, as technology continues to advance, the cost of storage space should continue to drop, and this is not thought to be a significant problem for the future. Students are currently being trained on e-Portfolio, and they seem to appreciate the instrument. 
Table 1. Proposed E-Portfolio Exhibits

Engineering, Physics, and Physical Science Department

\begin{tabular}{|c|c|}
\hline $\begin{array}{l}\quad \text { Entry Level } \\
\text { 1. E-Portfolio Agreement Form } \\
\text { 2. Essay on Stewardship/Ethics } \\
\text { 3. Glider Design Project Report } \\
\text { 4. Video Clip of Glider Presentation } \\
\text { 5. Self-evaluation of Presentation } \\
\text { 6. Reflection on Presentation } \\
\text { 7. Engineering Graphics Exam } \\
\text { 8. ORU GPA (Transcript) } \\
\text { 9. Initial Resume } \\
\text { 10. Sophomore Interview }\end{array}$ & $\begin{array}{l}\quad \text { Intermediate Level } \\
\text { 1. Physics II Project Report } \\
\text { 2. Video Clip of Project Presentation } \\
\text { 3. Self-evaluation of Presentation } \\
\text { 4. Reflection on Presentation } \\
\text { 5. Network Analysis I Exam } \\
\text { 6. Electronics I Lab Report } \\
\text { 7. Statics Exam } \\
\text { 8. Two Disposition Evaluations } \\
\text { 9. Verification of Extracurricular } \\
\text { Involvement } \\
\text { 10. Professional Development Plan to } \\
\text { Address Areas of Improvement } \\
\text { 11. Application for Candidacy }\end{array}$ \\
\hline \begin{tabular}{ll} 
& \multicolumn{1}{c}{ Capstone Level } \\
1. & Engineering Economics Paper \\
2. Senior Project Report \\
3. Video Clip of Project Presentation \\
4. Self-evaluation of Presentation \\
5. Reflection on Presentation \\
6. Revised Resume \\
7. & FE Exam Results \\
8. & Two Professional References
\end{tabular} & $\begin{array}{l}\quad \text { Professional Level } \\
\text { 1. Exit Interview Questionnaire } \\
\text { 2. Grad School Advisor Survey } \\
\text { 3. Employer Survey } \\
\text { 4. }\end{array}$ \\
\hline
\end{tabular}


Table2. Assessment Rubric for EGR 221 - Mechanics I: Statics Examination

\begin{tabular}{|c|c|c|c|c|c|}
\hline Category & Exemplary & Competent & Acceptable & Unacceptable & Unattempted \\
\hline Information & $\begin{array}{l}\text { Problem is } \\
\text { completely } \\
\text { and clearly } \\
\text { restated, and } \\
\text { necessary } \\
\text { information is } \\
\text { accurately } \\
\text { applied. }\end{array}$ & $\begin{array}{l}\text { Problem is } \\
\text { partially } \\
\text { restated, and } \\
\text { necessary } \\
\text { information is } \\
\text { accurately } \\
\text { applied. }\end{array}$ & $\begin{array}{l}\text { Necessary } \\
\text { information is } \\
\text { accurately } \\
\text { applied. }\end{array}$ & $\begin{array}{l}\text { Incorrect or } \\
\text { inappropriate } \\
\text { information is } \\
\text { applied. }\end{array}$ & $\begin{array}{l}\text { Information is } \\
\text { not applied. }\end{array}$ \\
\hline Assumptions & $\begin{array}{l}\text { Appropriate } \\
\text { assumptions } \\
\text { are applied } \\
\text { and listed } \\
\text { along with } \\
\text { explanations } \\
\text { of relevant } \\
\text { implications. }\end{array}$ & $\begin{array}{l}\text { Appropriate } \\
\text { assumptions } \\
\text { are applied, } \\
\text { with the } \\
\text { primary } \\
\text { assumptions } \\
\text { listed. }\end{array}$ & $\begin{array}{l}\text { Appropriate } \\
\text { assumptions } \\
\text { are applied. }\end{array}$ & $\begin{array}{l}\text { Incorrect or } \\
\text { incomplete } \\
\text { assumptions } \\
\text { are applied. }\end{array}$ & $\begin{array}{l}\text { Assumptions } \\
\text { are not } \\
\text { applied. }\end{array}$ \\
\hline Diagrams & $\begin{array}{l}\text { All pertinent } \\
\text { diagrams are } \\
\text { neatly and } \\
\text { correctly } \\
\text { drawn to } \\
\text { assist in the } \\
\text { solution } \\
\text { procedure }\end{array}$ & $\begin{array}{l}\text { All pertinent } \\
\text { diagrams are } \\
\text { correctly } \\
\text { drawn to } \\
\text { assist in the } \\
\text { solution } \\
\text { procedure }\end{array}$ & $\begin{array}{l}\text { Diagrams are } \\
\text { correctly } \\
\text { drawn to } \\
\text { assist in the } \\
\text { solution } \\
\text { procedure }\end{array}$ & $\begin{array}{l}\text { Incorrect or } \\
\text { illegible } \\
\text { diagrams are } \\
\text { drawn }\end{array}$ & $\begin{array}{l}\text { Diagrams are } \\
\text { not drawn. }\end{array}$ \\
\hline Formulas & $\begin{array}{l}\text { Governing } \\
\text { mathematical } \\
\text { and physical } \\
\text { relations are } \\
\text { accurately \& } \\
\text { efficiently } \\
\text { applied in a } \\
\text { logical } \\
\text { sequence. }\end{array}$ & $\begin{array}{l}\text { Governing } \\
\text { mathematical } \\
\text { and physical } \\
\text { relations are } \\
\text { accurately } \\
\text { applied in a } \\
\text { logical } \\
\text { sequence. }\end{array}$ & $\begin{array}{l}\text { Governing } \\
\text { mathematical } \\
\text { and physical } \\
\text { relations are } \\
\text { accurately } \\
\text { applied. }\end{array}$ & $\begin{array}{l}\text { Incorrect or } \\
\text { incomplete } \\
\text { mathematical } \\
\text { and physical } \\
\text { relations are } \\
\text { applied, or } \\
\text { correct } \\
\text { relations are } \\
\text { misapplied. }\end{array}$ & $\begin{array}{l}\text { Mathematical } \\
\text { and physical } \\
\text { relations are } \\
\text { not applied. }\end{array}$ \\
\hline Solution & $\begin{array}{l}\text { Governing } \\
\text { relations are } \\
\text { quickly } \\
\text { solved for the } \\
\text { desired } \\
\text { quantities, } \\
\text { and a check is } \\
\text { conducted. }\end{array}$ & $\begin{array}{l}\text { Governing } \\
\text { relations are } \\
\text { quickly } \\
\text { solved for the } \\
\text { desired } \\
\text { quantities. }\end{array}$ & $\begin{array}{l}\text { Governing } \\
\text { relations are } \\
\text { solved for the } \\
\text { desired } \\
\text { quantities. }\end{array}$ & $\begin{array}{l}\text { Attempts to } \\
\text { solve for the } \\
\text { desired } \\
\text { quantities are } \\
\text { unsuccessful. }\end{array}$ & $\begin{array}{l}\text { No attempt is } \\
\text { made to solve } \\
\text { for the } \\
\text { desired } \\
\text { quantities. }\end{array}$ \\
\hline
\end{tabular}


Implementation of e-Portfolio will help to streamline the assessment process in engineering, since students assist in submitting exhibits. This has the added benefit of giving the students a closer view of how their lives are being transformed. It is expected that this will motivate them to higher levels of performance and further accomplishments. Faculty also will benefit by enjoying a more automated method of collecting and assessing student work.

Bibliography

1. Oral Roberts University Catalog 2002-2004. (2002). Edited by Sowell, D. and Gray, L., www.oru.edu.

2. The Holy Bible, New International Version.

3. Chalk and Wire. (2003). e-Portfolio and RubricMarker. St. Catherine's, ON, Canada: www.chalkandwire.com.

4. Fagin, R., Hand, D. and Boyd, K. (2003) Electronic Portfolios Aggregating and Disaggregating Data: Measuring a Transformed Life. Selected for presentation at the $109^{\text {th }}$ Annual Meeting of the North Central Association, March 27-30, Chicago.

5. ABET. (2003). Criteria for Accrediting Engineering Programs, Effective for Evaluations During the 20042005 Accreditation Cycle. www.abet.org.

Biography

DOMINIC MICHAEL HALSMER, PhD, PE, Professor, has chaired the Engineering and Physics Department at Oral Roberts University in Tulsa, Oklahoma for the last five years. Besides engineering education, his research interests include spacecraft attitude dynamics and controls, and aircraft design. He enjoys engaging in vigorous activities with his wife of 20 years; Kate, their four children, and the students and faculty of ORU. 